\title{
Biochemical Constituents Imparting Resistance to Sucking Pest Aphid in Cotton (Gossypium spp.)
}

\author{
T.C. Divya ${ }^{1}$, I.S. Katageri ${ }^{2 *}$, M.P. Jadhav², Sateesh Adiger ${ }^{2}$, \\ H.M. Vamadevaiah ${ }^{1}$ and Nagaratna S. Olekar ${ }^{1}$ \\ ${ }^{1}$ Department of Biochemistry, ${ }^{2}$ Department of Biotechnology, University of Agricultural \\ Sciences, Dharwad, Karnataka, India \\ *Corresponding author
}

\section{A B S T R A C T}

\begin{tabular}{|c|}
\hline Keywords \\
\hline $\begin{array}{l}\text { Cotton, Sucking pest, } \\
\text { Total phenols, } \\
\text { Condensed tannin, } \\
\text { Lipoxygenase and } \\
\text { nitrate reductase. }\end{array}$ \\
\hline Article Info \\
\hline $\begin{array}{l}\text { Accepted: } \\
19 \text { October } 2017 \\
\text { Available Online: } \\
10 \text { December } 2017\end{array}$ \\
\hline
\end{tabular}

\section{Introduction}

Since $6000 \mathrm{BC}$, cotton has been cultivated for lint fiber, which now dominates the natural textile industry worldwide. Cotton fibers sustain one of the world's largest industries, the textile industry, for wearing apparel, home furnishings, and medical supplies. Cottonseed oil is ranked fifth in production and consumption volume among all vegetable oils in the past decades, accounting for $8 \%$ of the world's vegetable oil consumption. It provides $65 \%$ raw material to textile industry and contributes one third of total foreign exchange earning of India (Mayee and Rao, 2002).
Out of the Gossypium species, four are cultivated in agriculture, including two allotetraploids ( $G$. hirsutum and $G$. barbadense) and two diploids ( $G$. herbaceum and G. arboreum). Gossypium hirsutum, also known as Upland cotton, Long Staple Cotton, or Mexican Cotton, produces over $90 \%$ of the world's cotton whereas the other three Gossypium species are grown only on comparably small areas. These genotypes were most likely domesticated independently of each other (Fryxell, 1979). Among the several reasons of low yield, the magnitude of insect-pests which damage the cotton crop 
from sowing to maturity plays an important role. The insect-pests on an average cause 510 percent of losses but under several insectpests infestations can cause heavy qualitative and quantitative losses varying from 40-50\% (Naqvi, 1976). Cotton insect pest complex is divided into two categories; sucking insect pests and chewing insect pests. Important sucking insect pests are whitefly, Bemisia tabaci (Genn.), thrips, Thrips tabaci (Lind.) jassid, Amrasca devastans (Dist.) and aphid, Aphis gossypii (Glov.) which is also designated as key pests causing most of the damage to the cotton crop.

The mechanism of host plant resistance in response to insect infestation consists of a series of biochemical events, including increased production of phenolics, mediated by phenylalanine ammonia-lyase, tyrosine ammonialyase, peroxidase and polyphenol oxidase. The primary metabolites include carbohydrates and proteins, which are exploited by the herbivores for their growth and development. These primary metabolites also function as precursors of secondary substances, which are major elements of resistance in plants. The secondary substances determine the suitability of the substrate for colonization and exploitation by the herbivores and thus govern host preferences and acceptability. Age correlated biochemical profiles of host tissues also significantly influence infestation patterns.

Metabolites play a major role in the adaptation of plants to the changing environment and in overcoming stress constraints. This flows from the large complexity of chemical types and interactions underlying various functions namely structure stabilizing, determined by polymerization and condensation of phenols and quinones, or by electrostatic interactions of polyamines with negatively charged loci in cell components; as well as aromatic nuclei and unsaturated aliphatic chains and signal transduction, several plant-biotic and abiotic stress stimuli systems, multiplicity of biochemical mechanisms involved in the protective role by metabolites (Edreva, 2008).

Therefore the aim of present work was, to study the defence mechanism of cotton cultivars against sucking pest aphid, the oxidative responses since they thought to have an important role as antiherbivores.

\section{Materials and Methods}

In order to study the factors responsible for resistance to sucking pest aphid infestation, the experiment was conducted during kharif 2015-16 at ARS Dharwad farm. Two genotypes were used to study resistant CPD14-1 genotype and susceptible CPD14-2 genotype. In the field one uninfected set was maintained as control by regular spraying and cages lined with nylon mesh to maintain plants free from insect pests and the other set of plants were allowed for naturally aphid infestation and aphid population per plant were recorded and analysis of the biochemical constituents were performed at an interval of 45, 85 and 125 DAS.

\section{Sample preparation}

Five plants were randomly selected from each treatment. The top three leaves from the control and infested leaves were chosen for biochemical analysis.

\section{Estimation of total phenol and tannin content}

For total phenol estimation $100 \mathrm{mg}$ of oven dried leaf sample was extracted in $10 \mathrm{ml}$ of warm $80 \%$ ethanol. Then, it was cooled and passed through double layered muslin cloth. The residue of the tissue was ground thoroughly in a morter pestle with hot 
alcohol. It was passed through muslin cloth repeated to obtain sufficient amount of extract. The extract was polled and filtered through Whatman NO. 41 filter paper and made up to $10 \mathrm{ml}$ volume with alcohol and stored in a refrigerator at $4^{\circ} \mathrm{C}$. Total phenols were estimated by Folin-Ciocalteau reagent (FCR) method (Bray and Thorpe, 1954).Tannin was estimated by Folin- Denis reagent (FDR) method (Chan et al., 1978).

\section{Estimation of nitrate reductase activity}

Nitrate reductase activity in the leaves was determined by using colorimeter (Hageman and Reed, 1980). A known weight (140 mg) of fresh leaf tissue was cut into pieces and suspended in screw cap vials containing $3.5 \mathrm{ml}$ of incubation mixture $(20 \mathrm{ml}$ of $0.1 \mathrm{M}$ phosphate buffer $p^{\mathrm{H}} 7.5+20 \mathrm{ml}$ of 5 per cent propanol $+10 \mathrm{ml}$ of 0.2 per cent $\mathrm{KNO}_{3}$ ). The vials are sealed and kept in dark condition at $30^{\circ} \mathrm{C}$ for $2 \mathrm{hr}$. Nitrite released into the medium was determined by treating $1 \mathrm{ml}$ aliquote with $1 \mathrm{ml}$ each of 1 percent sulphanyl amide and 0.02 per cent $\mathrm{N}-1$-napthyl ethylene diamine hydrochloride. After $20 \mathrm{~min}$, solution is diluted to $5 \mathrm{ml}$ with water (final volume should be $5 \mathrm{ml}$ ) and absorbance is measured at $540 \mathrm{~nm}$. Standard curve was prepared by using different grade concentrations of nitrite $\left(\mathrm{KNO}_{2}\right)$ solution. The nitrate reductase activity is expressed as nmoles of $\mathrm{NO}_{2}$ formed per gram fresh weight per hour.

\section{Estimation of lipoxygenase activity}

\section{Enzyme extraction and assay}

$1 \mathrm{gm}$ of fresh leaf sample was ground using $5 \mathrm{ml}$ of $0.1 \mathrm{M}$ Phosphate buffer, $\mathrm{pH} 6.5$ at $4^{0} \mathrm{C}$, centrifuge at $13000 \mathrm{rpm}$ for $20 \mathrm{~min}$ at $4^{0} \mathrm{C}$, supernatant was collected and used as an enzyme source. Lipoxygenase activity in the leaves was determined colorimetrically (Grayburn et al., 1991). 29.9ml of linoleic acid was taken in $100 \mathrm{ml}$ volumetric flask and maintained at $30^{\circ} \mathrm{C}$ using hot water bath. Aerate gently by gentle steam of air for $2 \mathrm{~min}$ and start the reaction by adding $0.1 \mathrm{ml}$ of enzyme extract. $1 \mathrm{ml}$ of solution was taken from the reaction mixture and transfer to glass tube containing $4 \mathrm{ml}$ of $0.1 \mathrm{~N} \mathrm{NaOH}$ at different time interval of $0.5,1,1.5,2$ and 2.5 minutes. Simultaneously kept a blank with $1 \mathrm{ml}$ substrate and $0.1 \mathrm{~N} \mathrm{NaOH}$, absorbance was taken at $234 \mathrm{~nm}$.

\section{Statistical Analysis}

The data of the experiment was analyzed statistically following the procedure described by Gomez and Gomez (1984). The level of significance used in ' $F$ ' and' $t$ ' test was $p=$ 0.05 . The critical difference was calculated wherever the ' $F$ ' value was found to be significant by using 3 factorial RCBD (Randomized Complete Block Design).

\section{Results and Discussion}

\section{Total phenols}

The phenol content of resistant CPD14- 1 in control plant at 45, 85 and 125 DAS were (7.35, 6.82 and $6.42 \mathrm{~g} / 100 \mathrm{~g}$ dry weight) and the susceptible CPD14-2 genotype recorded $(6.88,6.52$ and $6.35 \mathrm{~g} / 100 \mathrm{~g}$ dry weight) respectively as shown in (Fig. 1). However the phenol content was increased under insect damage.

The increase was more in CPD14-1 at 45, 85 and 125 DAS $(7.6,7.28$ and $6.96 \mathrm{~g} / 100 \mathrm{~g}$ dry weight) than CPD14-2 (7.19, 6.79 and 6.62 $\mathrm{g} / 100 \mathrm{~g}$ dry weight). Results presented in table revealed that the resistant genotype exhibited higher total phenol content compared to susceptible under both control and insect damage and also the total phenol content in both the genotype decreased as the age of the crop advanced. 
The results are in line with the findings Kalappanavar and Hiremath (2000) reported higher phenol content in multiple foliar disease resistant sorghum genotypes than susceptible ones. Jain and Yadav, 2003 (2003) who reported total phenol act as antioxidant enzyme substrates. As the high concentrations of phenolic acids are related to resistance to pest (Usha Rani and Jyothsna, 2010), the increased quantity of total phenols might also be attributed to defense mechanism. After infection by a pathogen, plant cells synthesize phenol oxidizing enzymes that oxidise phenols into toxic quinines, which play a crucial role in disease resistance (Jiang et al., 2009). Based on these findings, it could be concluded that rapid accumulations of phenolic compounds occur in incompatible (resistant) host pathogen interaction than the compatible (susceptible) ones.

\section{Condensed tannin}

The tannin content of both the genotypes under control and insect damage was measured and percentage decrease was calculated (Table 1). Tannin content of CPD14-1 genotype at 45,85 and 125 DAS under insect damage was $(9.20,8.78$ and 7.53 $\mathrm{g} / 100 \mathrm{~g}$ dry weight), while under control (8.43, 7.58 and $6.32 \mathrm{~g} / 100 \mathrm{~g}$ dry weight). On the other hand in insect damage CPD14-2 recorded $(8.41,7.76$ and $6.28 \mathrm{~g} / 100 \mathrm{~g}$ dry weight), respectively, while under control (7.54, 6.87and $5.36 \mathrm{~g} / 100 \mathrm{~g}$ dry weight).

The results indicated that CPD14-2 susceptible genotype recorded significantly lower tannin content than resistant CPD14-1 with percentage reduction $(-25.3-28 \% \quad 125$ over 45DAS). The results of the experiment are in agreement with the findings of Somashekara et al.,(2003) the extremity in tannin content of plant was observed among the two groundnut varieties, NAC-6004 was having highest total tannin content as compared to verity CM-300 showed lower tannin content. Khurana et al., (19897) the higher concentration of total tannin had been reported to show antibiotic effect in sorghum against shoot fly and stem borer. However, tannins were associated with repellency or deterrency and jointly contributed to the protection of plant along with other phytochemicals like phenols. Since, tannin present in plant has a role in anti-feedants properties of plant and protects it from being attacked by the pest and diseases.

\section{Lipoxygenase}

The leaves of infected resistant genotype showed higher activity of lipoxygenase at 45 , 85 and 125 DAS $(4.09,3.83$ and $3.13 \mathrm{U} / \mathrm{mg}$ of protein respectively), compared to infected susceptible genotype (2.43, 2.09 and 1.78 $\mathrm{U} / \mathrm{mg}$ of protein). Lipoxygenase activity also increased under control resistant genotype (3.73, 3.12 and $2.65 \mathrm{U} / \mathrm{mg}$ of protein), but it was lower than infected resistant (Table 2). LOX activity was more in insect damage treatment, significantly higher LOX activity was recorded in CPD14-1 genotype with per centage reduction 6.35 per cent in 85DAS over 45DAS and 23.47 per cent in 125 over 85DAS. CPD14-2 genotype recorded significant lower LOX activity with percentage reduction 13.9 per cent in 85DAS over 45DAS and 26.7 per cent in 125 over 85DAS.

The phenomenon of increased lipoxygenase activity due to stress is attributed by various reasons. Mahatma et al., 2011, a higher level of LOX activity was observed in Fusarium udum inoculated resistant pigeon pea cultivar than in susceptible cultivar. The increased LOX may generate signal molecules such as jasmonic acid, methyl jasmonic acid or lipid peroxides, which co-ordinately amplify specific responses. 
Table.1 Effect of insect damage on accumulation of Tannin content in cotton leaf at different stages of crop growth

\begin{tabular}{|c|c|c|c|c|c|c|c|c|c|c|c|c|c|}
\hline \multirow[b]{3}{*}{ Genotype } & \multicolumn{13}{|c|}{ Tannin(mg/g dry weight) } \\
\hline & \multicolumn{6}{|c|}{ Control } & \multicolumn{7}{|c|}{ Insect Damage } \\
\hline & 45 DAS & 85 DAS & $\begin{array}{l}125 \\
\text { DAS }\end{array}$ & \begin{tabular}{|l} 
Per cent \\
decrease \\
in 85 \\
DAS \\
over 45 \\
DAS
\end{tabular} & $\begin{array}{l}\text { Per cent } \\
\text { decrease } \\
\text { in } 125 \\
\text { DAS } \\
\text { over } 45 \\
\text { DAS }\end{array}$ & Mean & $\begin{array}{l}45 \\
\text { DAS }\end{array}$ & $\begin{array}{l}85 \\
\text { DAS }\end{array}$ & $\begin{array}{l}125 \\
\text { DAS }\end{array}$ & \begin{tabular}{|l} 
Per cent \\
decrease \\
in 85 \\
DAS \\
over 45 \\
DAS
\end{tabular} & \begin{tabular}{|l} 
Per cent \\
decrease \\
in 125 \\
DAS \\
over 45 \\
DAS
\end{tabular} & Mean & $\begin{array}{l}\text { Grand } \\
\text { mean }\end{array}$ \\
\hline CPD14-1 & 8.43 & 7.58 & 6.32 & -10.08 & -25.02 & 7.44 & 9.20 & 8.78 & 7.53 & -4.56 & -18.15 & 8.5 & 7.97 \\
\hline CPD14-2 & 7.54 & 6.87 & 5.36 & -8.88 & -28.91 & 6.59 & 8.41 & 7.76 & 6.28 & -7.72 & -25.32 & 7.48 & 7.03 \\
\hline $\begin{array}{l}\text { Per cent } \\
\text { increase or } \\
\text { decrease } \\
\text { over } \\
\text { CPD14-2 }\end{array}$ & -10.55 & -9.36 & -15.8 & & & -11.4 & -8.58 & -11.6 & -16.6 & & & -12 & -11.79 \\
\hline $\begin{array}{l}\text { Grand } \\
\text { mean }\end{array}$ & 7.98 & 7.22 & 5.84 & & & 7.01 & 8.8 & 8.27 & 6.90 & & & 7.99 & \\
\hline & & & & \multicolumn{5}{|c|}{ S.Em \pm} & \multicolumn{5}{|c|}{ CD@1\% } \\
\hline Factor $\mathrm{G}$ & & & & \multicolumn{5}{|c|}{0.015} & \multicolumn{5}{|c|}{0.058} \\
\hline Factor $\mathrm{T}$ & & & & \multicolumn{5}{|c|}{0.015} & \multicolumn{5}{|c|}{0.058} \\
\hline Factor D & & & & \multicolumn{5}{|c|}{0.019} & \multicolumn{5}{|c|}{0.071} \\
\hline $\mathrm{G} \times \mathrm{T}$ & & & & \multicolumn{5}{|c|}{$\mathbf{0 . 0 2 2}$} & \multicolumn{5}{|c|}{0.082} \\
\hline$G \times D$ & & & & \multicolumn{5}{|c|}{0.027} & \multicolumn{5}{|c|}{0.101} \\
\hline $\mathrm{T} \times \mathrm{D}$ & & & & \multicolumn{5}{|c|}{0.027} & \multicolumn{5}{|c|}{0.101} \\
\hline GxT $\times$ D & & & & \multicolumn{5}{|c|}{0.038} & \multicolumn{5}{|c|}{0.143} \\
\hline
\end{tabular}


Table.2 Effect of insect damage on accumulation of Lipoxygenase activity in cotton leaf at different stages of crop growth

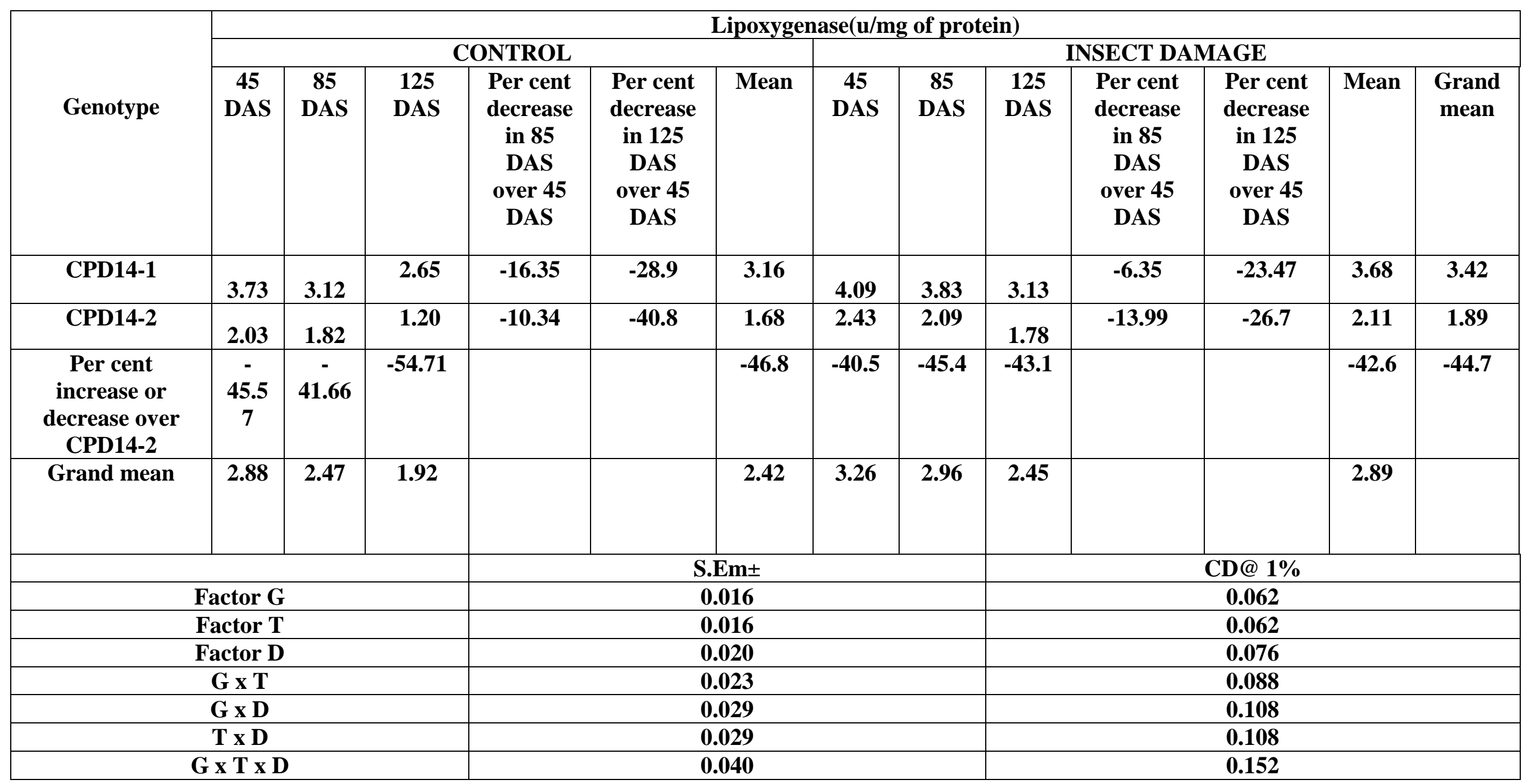


Fig.1 Effect of insect damage on accumulation of phenol content in cotton leaf at different stages of crop growth

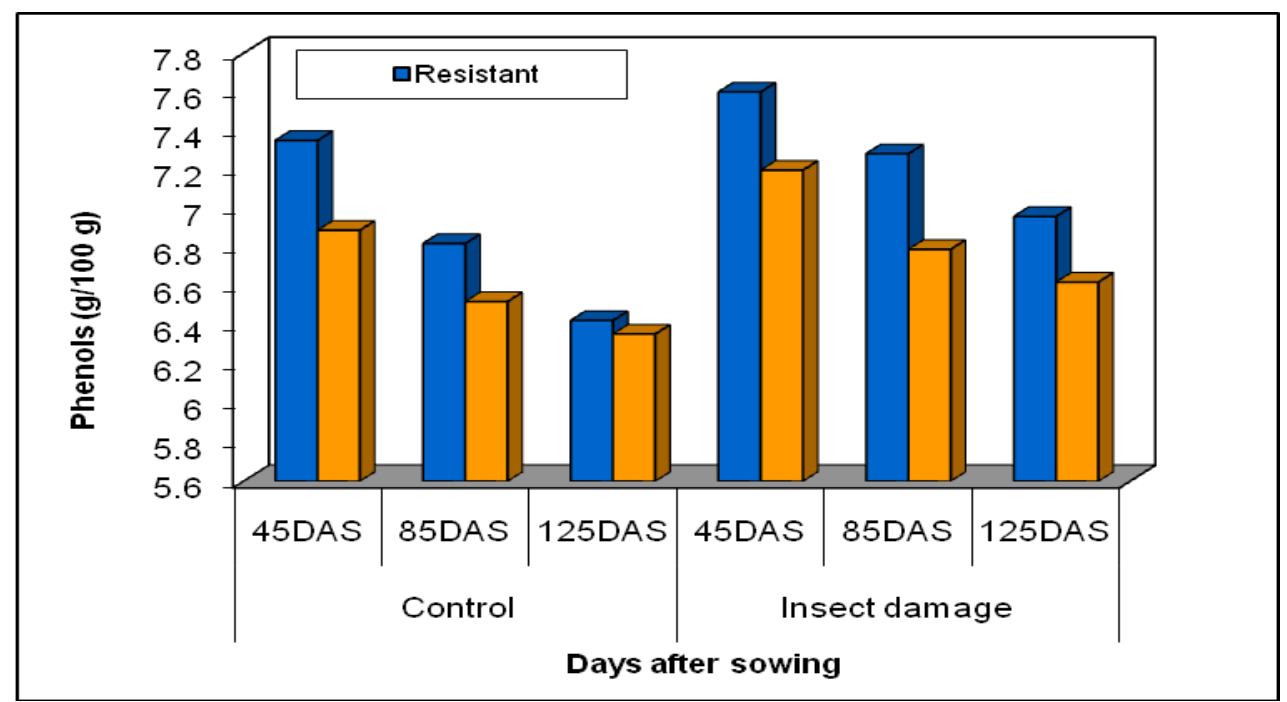

Fig.2 Effect of insect damage on accumulation of Nitrate reductase activity in cotton leaf at different stages of crop growth

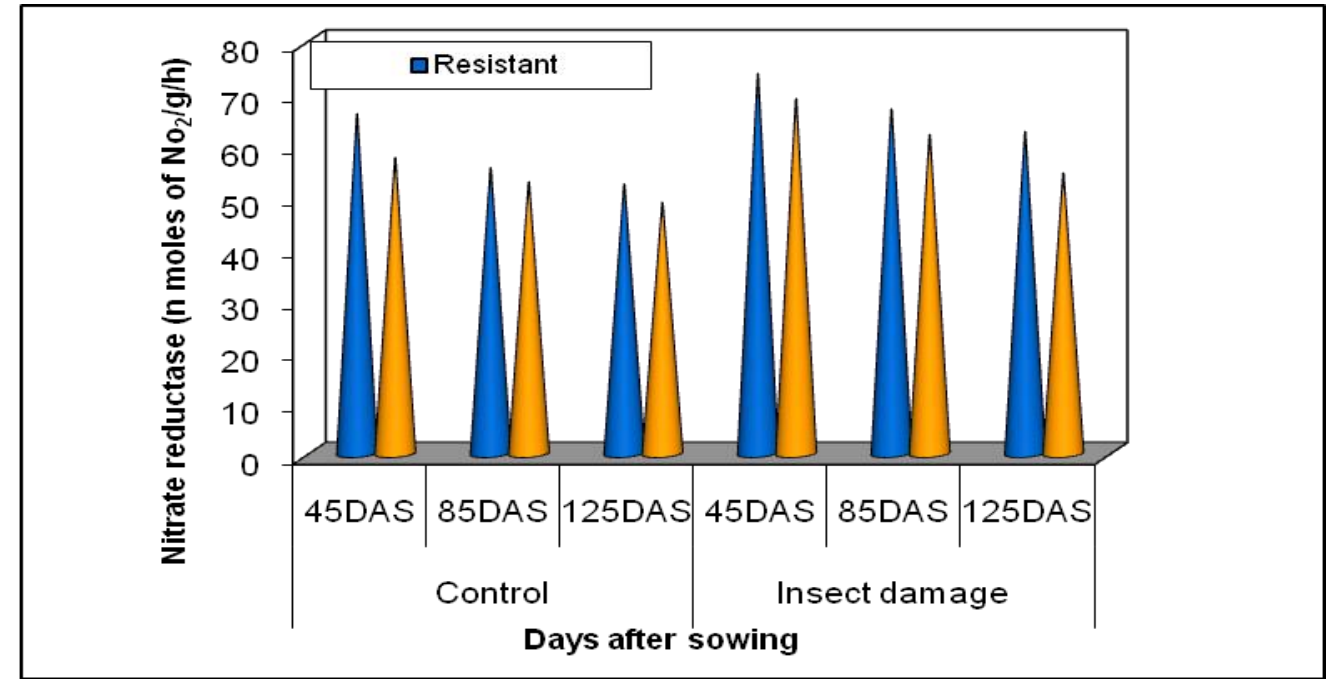


Alternatively, LOX catalyzed reactions can result in the production of toxic volatile and non-volatile fatty acid derived secondary metabolites that can directly attack invading pathogens (Croft et al., 1993). Increased LOX activity may also cause irreversible membrane damage, which would lead to the leakage of cellular contents (Mac Carrone et al., 2000).

\section{Nitrate reductase activity}

The nitrate reductase activity was decreased as the age of the crop advances as shown in (Fig. 2). CPD14-1 recorded significantly higher nitrate reductase activity at 45, 85 and 125DAS (73.3, 66.7 and 62.3 nmoles of $\left.\mathrm{NO}_{2} / \mathrm{g} / \mathrm{h}\right)$ under insect damage than control (65.85, 55.36 and 52.2 nmoles of $\left.\mathrm{NO}_{2} / \mathrm{g} / \mathrm{h}\right)$. CPD14-2 genotype recorded lowest nitrate reductase activity in control $(57.38,52.61$ and $8.67 \mathrm{nmoles}$ of $\mathrm{NO}_{2} / \mathrm{g} / \mathrm{h}$ ) and also insect damage (68.7, 61.7 and 54.3 nmoles of $\left.\mathrm{NO}_{2} / \mathrm{g} / \mathrm{h}\right)$ respectively.

The increased NRase activity was attributed to various reasons as follows; the nitrate reductase activity was more in the control than in stressed plants. The NRase, is a substrate inducible enzyme, mediates conversion of nitrate to nitrite. Ananthi and Vijayaraghavan, (2012), observed Nitrate reductase activity was found to be more in $\mathrm{KC} 2$ and AS2 which may be tolerant than the susceptible genotype of cotton. Sivaramakrishnan et al., (1988) studied the midseason drought indicating that there is a sharp decline in NRase activity under water stress situation. NRase activity was found to be more in $\mathrm{KC} 2$ and AS2.

This research offers a new perspective on cotton plant resistance against aphid and provides a model for studying insect plant interactions. Furthermore, the identification of biochemical constituents for aphid resistance provides a novel approach for screening resistant cotton cultivars for further breeding programme or as will act as gene source. Ultimately, biochemical constituents identified from this research will provide a set of tools for screening cotton cultivars for resistance to aphids.

\section{References}

Afzal, M. and Bashir, M.H., 2007, Influence of certain leaf characters of some summer vegetables with incidence of predatory mites of the family Cunaxidae. Pak. J. Bot.,, 39: 205-209.

Ananthi, K. and Vijayaraghavan, H., 2012, Soluble protein, nitrate reductase activity and yield responses in cotton genotypes under water stress. Insight Biochemistry, 2 (1) : 14.

Bashir, M.H., Afzal, M., Sabri, M.A. and Raza, A.M.,2001, Relationship between sucking insect pests and physio-morphic plant characters towards resistance/susceptibility in some new cotton genotypes of cotton. Pak. Entomol, 23:75-78.

Bray, H. G. and Thorpe, W. Y., 1954, Analysis of phenolic compounds of interest in metabolism. In: Moth Biochem, Annual (Ed.) Glick, D., Intersarnae Publishing Inc., New York, $1: 27-52$.

Chan, B. G., Waiss, A. C., and Lukefahr, M. J., 1978, Condensed tannin, an antibiotic chemical from Gossypium hirsutum, $J$. Insect. Physiol. 24: 113-118.

Croft KPC, Juttner F, Slusarenko A.J., 1993, Volatile products of the lipoxygenase pathway evolved from Phaseolus syringae pv phaseolicola. Plant Physiol 101:13-24.

Edreva A., Velikova, V., Tsonev, T., Dagnon, S., Gürel A., Aktaş, L. and Gesheva, E., (2008), Stress-protective role of secondary metabolites : diversity of functions and mechanisms Gen. Appl. Plant Physiol. (special issue), 34(1-2) :67-78.

Fryxell, P.A., 1979,Natural History of the Cotton Tribe. Texas A\&M Universit Press, Colleges Station, Texas, USA.

Gomez, K. A. and Gomez, A. A. 1984, Statistical Procedures for Agricultural Research, WileyInterscience, New York, pp. 97-107.

Grayburn, W. S., Schneider, G. R., Hamilton- 
Kemp, T. R., Bookjalis, G., Ali, K. And Hildebrandt, D. F., 1991, Soybean leaves contain multiple lipoxygenases, Plant Physiol., 95 : 1214-/1218.

Hageman, R. H. and Reed, A. J., 1980, Methods in Enzymology, 69 Part C (Ed Anthony san pietro) Academic Press New York., pp. 491530.

Hopkins,W.G. and Huner, N.P., 2004, Introduction to plant physiology. John Wiley and Sons. Inc., USA. pp.479-481.

Jain A.K. and Yadav H.S. 2003, Biochemical constituents of finger millet genotypes associated with resistant to blast caused Pyricularis grisea. Ann. Pl. Protec. Sci. 11: 70-74.

Jiang Y.F., Cheng W.D., Qin L.Q., Tan X.J., Zhou J.G., Xie H.X., Chen L. 2009, Physiological mechanism of exogenous salicylic acid induced resistance to sheath blight of maize (Zea mays L.). Guangxi Agri. Sci. 40: 242245.

Kalappanavar, I.K. and Hiremath,R.V., 2000, Biochemical factors for multiple resistance to foliar diseases of sorghum. Madras Agric. J. 87: 66-70.

Khurana AD, Verma AN (1983) Some biochemical plant characters in relation to susceptibility of sorghum to stem borer and shoot fly. Ind J Ent $45: 29-37$.

Mac Carrone M, Van ZG, Veldink GA, Vliegenthart JF, Finazzi AA (2000) Early activation of lipoxygenase in lentil (Lens culinaris) root protoplasts by oxidative stress induced programmed cell death. Eur J Biochem 267:5074-5084.

Mahatma,M.K., Bhatnagar R, Mittal GK, Mahatma L (2011) Antioxidant metabolism in pearl millet genotypes during compatible and incompatible interaction with downy mildew pathogen. Arch Phytopathol Plant
Protect 44(9):911-924.

Malk, P.C., Udayburman and Satish,L.,2000, Effect of planting dates and development of yellow mosaic virus on biochemical constituents of mothbean genotypes. Indian Phyto pathology 53:379-383.

Mayee, C. D. and Rao, M.R., 2002, Current cotton production and protection scenarios including G. M. cotton. Agrolook, AprilJune. pp. 14-20.

Naqvi, K.M., 1976, Crop protection to boost up cotton production. Proc. Cotton. Prod. Seminar, Organized by ESSO Fert. Co. Ltd., Pak. 119-125 pp.

Raza, A.M. and Afzal, M., Physio-morphic plant characters in relation to resistance against sucking insect pests in some new cotton genotypes. Pak. Entomol., 2000, 22:73-78.

Sivaramakrishnan, S., Parell, V.Z., Flower, D.J. and Peacock, J.M., 1988, Proline accumulation and nitrate reductase activity in contrasting sorghum lines during mid-season drought stress, Physiol.Plant., 74: 418-426.

Somashekar, O.N., Patil, B.V., 2003, Mechanisms of resistance in groundnut cultivars against thrips. Proc. Natl.Symp on Frontier Area of Entomol.401-402.

Sudha, G. and Ravishankar,G.A.,2002, Involvement and interaction of various signaling compounds on the plant metabolic events during defense response, resistance to stress factors, formation of secondary metabolites and their molecular aspects. Plant Cell Tissue and Org Cul 71: 181-212.

Usha Rani, P., Sandhyarani, K., 2012. Specificity of systemically released rice stem volatiles on egg parasitoid, Trichogramma japonicum Ashmead behavior. J. Appl. Entomol. 136 (10), 749-760.

\section{How to cite this article:}

Divya, T.C., I.S. Katageri, M.P. Jadhav, Sateesh Adiger, H.M. Vamadevaiah and Nagaratna S. Olekar. 2017. Biochemical Constituents Imparting Resistance to Sucking Pest Aphid in Cotton (Gossypium spp.). Int.J.Curr.Microbiol.App.Sci. 6(12): 2749-2757.

doi: https://doi.org/10.20546/ijcmas.2017.612.319 